\title{
Binding international norms, jus cogens
}

\author{
Erjona Ramaj ${ }^{1}$
}

\begin{abstract}
Article 53 of the Vienna Convention of 1969 states that a treaty is considered invalid if it in conflict with existing norms of jus cogens, and under Article 64 of the treaty becomes invalid if it conflicts with a norm youngest of the same nature. The case Nicaragua against the United States made clear that the notion of jus cogens is steadily entrenched in international law, however, is still necessary to determine accurately that power rates referred to in Articles 53 and 64 of the Vienna Convention.

Jus cogens norms include more those norms relating to morality or natural law than with traditional positivist rates derived from State practice.

In general, this includes making aggressive war, crimes against humanity, war crimes, sea piracy, genocide, apartheid, slavery, and torture.

Jus cogens norms are norms of customary international law which are so important, it can not be changed through treaties.

Under the Vienna Convention on the Law of Treaties, any treaty that is contrary to jus cogens norms is invalid.

Jus cogens norms are not listed, there is no catalog, their determined by any authoritative body, but these rates come from judicial practices and political and social attitudes, which are not values static. Jus cogens norm of unconditional right international, accepted and recognized by the international community norm from which no deviation is permitted.

Unlike the common law, which traditionally requires the consent and It lets change obligations between states through treaties, norms jus cogens can not be violated by any state "through treaties international or local regulations or special customary, or even through general rules of customary not have the same normative force.
\end{abstract}

Key words: jus cogens, binding international norms, Vienna Convention, customary international law, international treaties.

\section{Introduction}

Because rates are rules of conduct aimed at regulating the relations and maintain stability in society, I have paid attention and definitely a great importance. Article 53 of the Vienna Convention of 1969 states that a treaty is considered invalid if it is in conflict with existing norms of jus cogens, and under Article 64 of the treaty becomes invalid if it conflicts with a norm youngest of the same nature. The case Nicaragua against the United States made clear that the notion of jus cogens is steadily entrenched in international law, however, is still necessary to determine accurately that power rates referred to in Articles 53 and 64 of the Vienna Convention. Jus cogens norms include more those norms relating to morality or natural law than with traditional positivist rates derived from State practice. 
In general, this includes aggressive war, crimes against humanity, war crimes, sea piracy, genocide, apartheid, slavery, and torture. Jus cogens norms are basic rates and any action contrary to the norm of jus cogens as a rule will be considered regardless of the fact that the situation could be repeated many times. In this sense, the jus cogens norms are eternal and will need an almost unanimous approval and a test weight of Jurassic opinion before such a rate to be replaced. Jus cogens norms are norms of customary international law which are so important, it can not be changed through treaties ${ }^{1}$.

Jus cogens norms are aimed more further development of international law rather than its codification.

The Latin word ius cogens ("binding") Law shows, in international law, the customary rules that aim to protect the values that are considered essential and can not be avoided in any way. Jus cogens is perceived by members of the so-called international community (in particular countries), as an absolutely essential right.

\section{- International community find what is right?}

Most authors define international law as a whole of rules that define the rights and duties of states in their relations. This is the classic definition of international law and can be found in most of the authors of the international law literature (Rivijera, Liszt, Estlake, Lawrence, etc.). All these consider the state as the sole subject of international law. Another group of authors regard the individual as the only international entity. This group consists Dugui, Krabbe, Politis, etc. According to them, international law is set of rules that governs the relationship between people belonging to different political groups. The third group comprises state the authors consider the main subject of international law, but also here to put the other entities and individuals.

\section{Jus cogens norms}

Jus cogens is welcomed by both conventions:

1. Vienna Convention on the Law of Treaties of 1969.

2. Vienna Convention on the Law of Treaties between States and International Organizations or exists between International Organizations of 1986.

- According to Article 53 of the Convention 1969

"This treaty is void if, at the time of its conclusion, it conflicts with a mandatory norm of general international law. For the purposes of this Convention, a mandatory norm of international law means a standard that is accepted and recognized by the international community of states as a whole as a norm from which no derogation is permitted and which can not be changed by the new norm of general international law having the same character. ${ }^{2}$ "

${ }^{1}$ Dixon Martin "INTERNATIONAL Law", page 125.

2 Vienna Convention on the Law of Treaties of 1969, Section 53. 


\section{- While Article 64 provides:}

"If a new norm of international law irrefutable general appears, any existing treaty which is in conflict with that norm becomes void and terminates. ${ }^{3 "}$

Article 103 of the Charter of the United Nations, said the case is sanctioned mandatory nature. So, in addition to these universal values that are considered by the international community seems to be qualified as mandatory requirements and principles proclaimed in the Charter of the United Nations ${ }^{4}$.

There is a relationship between the inner almost jus cogens and human rights. Standards of human rights are undeniable. As projections of individual and collective consciousness, powerful materialize as collective beliefs.

It is a body of binding norms with international character, aimed at maintaining basic human rights, on which there shall be no deviation or recourse.

Such as:

1. crimes against humanity,

2. war crimes

3. maritime piracy,

4. genocide,

5. apartheid

6. slavery

Jus cogens can, act to invalidate a treaty or agreement between countries in the extent of non-compliance with any rule or norm which violate basic human rights-based approach. Norms of international law and jus cogens particularly essentially protect human rights and non-discrimination of the latter.

\section{- Defining Treaty}

Vienna Convention on the Law of Treaties of 1969 defines a treaty as an international agreement concluded between States in written form and guided by international law (Article 2 (1) (a)). It should be noted that treaties could be concluded between the two countries or parties, or among more states, or parties. States that are party to a treaty called the contracting parties. States not party to a treaty called noncontracting parties.

\section{Treaties and customary international law}

There is a complex relation between treaty and customary international law. Normally, the treaty replaces customary international law that is inconsistent with it. Generally we can say that in the event of discrepancies, whichever is younger, if the norm customary or treaty prevails in relation to the same parties. Parties to a treaty may agree to abide by the treaty, even if established customary rate for the same issue. On the other hand, although the modification of the common law treaty is common, it is very

\footnotetext{
3 Vienna Convention on the Law of Treaties of 1969, Section 64

${ }^{4}$ The United Nations Charter, Article 103.
} 
rare that the common law rules developed contrary to the agreements once reached. Vienna Convention on the Law of Treaties makes detailed discussion of these principles ${ }^{5}$.

Parties to the Vienna Convention, taking into account the important role of treaties in the history of international relations, recognizing the consensual nature of treaties and their importance always growing as a source of international law. Noting that the principles of free consent, good faith and the rule pacta sunt servanda (lat. The agreements must be respected) are clearly (the Vienna Convention). Confirming the importance of increasing the codification process and increasing development of international law on a universal level. Believing that the codification and progressive development of the rules relating to treaties between States and international organizations or between international organizations themselves are a means of raising the rule of law in international relations and serving the goals of the United Nations.

Given the principles of international law embodied in the Charter of the United Nations, such as the principles of equal rights and self-determination of the people, equality and independence, sovereign of all states, non-interference in the internal affairs of states, stopping threats or use of force, the universal respect and implementation of human rights and fundamental freedoms for all ${ }^{6}$. Given the provisions of the Vienna Convention on the Law of Treaties of 1969. Considering the importance of treaties between States and international organizations or between international organizations as a useful means of developing international relations and security conditions for cooperation peace among nations, irrespective of their constitutional systems and social ${ }^{7}$. Given the special features of treaties to which international organizations are parties as subjects of international law states otherwise. Noting that international organizations have the capacity to connect the treaty, which is necessary for the exercise of their functions and fulfill their goals. Recognizing that the practice of international organizations in the conclusion of treaties with States or between themselves should be in accordance with their constituent instruments. Confirming that nothing in this Convention shall be construed to affect the relations between an international organization and its members, which relationship governed by the rules of the organization $^{8}$. Confirming also that disputes concerning treaties, like other international disputes, should be adjusted in accordance with the Charter of the United Nations by peaceful means and in accordance with the principles of justice and international law ${ }^{9}$.

\section{The international customary law}

Statute of the International Court of Justice "customary international as

5 See the J.M widely Henckaerts - Study on Customary International Humanitarian Law, p. 3-9 published electronically in Albanian on our website: htt p: //www.icrc.or g / We b / ng / eng site 0. nsf / htmlall / customary-law- translations_res / \$ File / ALB-irrc_857_Henckaerts.

6 The United Nations Charter, Article 106.

7 ICJ, North Sea Continental Shelf, ICJ Reports, 1969. the page 74

81986 Vienna Convention

${ }^{9}$ Law number 18/2014 on the accession of the Republic of Albania in the Vienna Convention of 1986. 
evidence of general practice accepted as law", is counted among the sources of international law applied by that Court, in its capacity as the main body judicial UN. Incompatibilities between different authors associated with other resources received, or the potential of public international law, generally does not affect the understanding of the custom widely accepted as the primary source of international law. ${ }^{10}$ "The scope of the law in the most reasonable answers to the description of international law is" general international law ". Since there is no authoritative lexicon of terms of international law, there is no general consensus on what is the content of international law. For some, international law is a synonym of "customary international law", for others, the term "international law" includes all international law is not limited to implementing only some states. Therefore, the category that most obvious way is excluded, are treaties. However, although it may seem confusing, some treaties put to general international law. On the other hand, some (the exception) are believed to be customary regional, and therefore, less universal. ${ }^{11}$

\section{- Metamorphosis of jus cogens norms}

When the Vienna Convention on the Law of Treaties confirmed the existence of norms of international law cut (jus cogens) they were conceived as Roman jus publicum, as absolute law can not be changed by the will of individual countries. ${ }^{12}$ The researchers then transformed the concept of public policy in the event (ordre public). They also argued for expanding the scope of its application for legal unilateral acts and customary international law. A recent trend in academic theory of jus cogens assigns a fundamental role in constitutionalizimin of international law, taking for granted that as the highest hierarchy of the order or the best way to embodying constitutional principles.

\section{The distinction between Jus cogens and obligations Erga omnes.}

To understand the importance and role of these two rules, we must first make a distinction between them, taking into account their different origins historical, and the effects of their mutual fields of application. Challenged the concept according to which only the rules that create obligations erga omnes can be regarded as indisputable. ${ }^{13}$ This critical analyzes how these misconceptions are reflected in the solutions, although contradictory, adopted by the International Law Commission on the final draft on responsibility of States adopted in 2001.

\section{- $\quad$ Erga Omnes}

Rate is valid against the whole world. For example, the right to property is right "erga

\footnotetext{
10 Of-the-human-rights-of-hedge-international.

11 Gardiner, R.K. International Law. (Harlow: Longman, 2003) [ISBN 0582369762] page.98

12 (Karl Zemanek) The Metamorphosis of Jus Cogens: From an Institution of Treaty Law to the Bedrock of the International Legal Order?

13 (Paolo Picone) The Law of Treaties Beyond the Vienna Convention
} 
omnes" and therefore apply to anyone who violates this right.

Decisions to declare the unconstitutionality of the law have value erga omnes. They belong to all citizens and not just the parties to whom they belong the court case 14

\section{- Obligations erga omnes}

Erga omnes obligations understand those entities which are authorized entity quality and liable not only have obligations to them, but there may be a third party, and the obligations I encounter easements. Erga Omnes ie to all. ${ }^{15}$

We must understand the notion of conflict between treaties and jus cogens. It is suggested that the classic notion of conflict - understood as the inability to apply two mutually exclusive rules the same time - is inappropriate about the relationship between common law rules high. A broader notion of conflict, which includes other forms of interference between top law and low law should be adopted instead. This broad notion may also contribute to define the role of jus cogens in the legal regime of state responsibility. ${ }^{16}$

\section{Conclusion}

By This survey we determined that jus cogens norms of general international law are not controversial and any treaty which is in violation of the right to fair with these norms, automatically appointed as void and goes out each function. The international community of states, I have fully recognized and accepted as jus cogens norms of international law for purposes of the present Convention. As a norm from which deviation is not allowed, and which can be modified only by a subsequent norm of general international law, which has a similar character. Article 64 is also important to note in this case: If a new norm of jus cogens appears, any existing treaty which is in conflict with that norm becomes void and cease to exist. The international law of treaties is usually a reflection of customary international law. The right of treaties may also guide the evolution of customary international law, because the states are not party to the treaty by the rules established by treaty.

The study shows that many rules of customary international law as valid and applicable in international armed conflicts alike Non- international and demonstrates the extent to which State practice has surpassed the existing treaty law and expanded the rules applicable in armed conflict Non- international.

It remains to be examined to what extent, from a humanitarian and military perspective, this more detailed and complete and should also examine whether there is a need for further development of this law. As is the case for treaty law, effective implementation of the rules of customary international humanitarian law is required through dissemination, training and enforcement. These rules should be incorporated into military manuals and national legislation, wherever are not included.

\footnotetext{
14 legislation-national / module-i / principle-of-constitutionality-and-legality

15 (Paolo Picone) The Law of Treaties Beyond the Vienna Convention

16 (Enzo Cannizzaro) The Law of Treaties Beyond the Vienna Convention
} 


\section{References}

[1] Supreme Court decision No. 8 dated 10,06,2011 registered on charter No. 7 Tirana Albania.

[2] Supreme Court decision dated 05.08.2014 Tirana Albania.

[3] Zaganjori, Xhezair, "Place of international law in the Constitution of the Republic of

Albania", published "Life Law", No. 2, February 2004.

[4] Anastasi Aurela, institutionalization of constitutional law, constitutional provisions of

[5] Albania's integration. The agreement of trade and cooperation May 11, 1992.

[6] Canaj Erjona, Bana Sokol ,of European Union Law, lectures in 2009.

[7] Barile Cheli di Grassi Instituzioni dirito public.

[8] The Constitution of the Republic of Albania in 1998.

[9] European reunification CARDS Programme for Albania Booklet 3.

[10] Dixon Martin international law.

[11] Puto Arben of Public International Law.

[12] Show Malcolm of international law.

[13] Kellerman Alfred impact of EU membership in a range of interior law of the Republic of Albania,published in the journal "parliamentary law and legal poliotikat" No.1. 2007.

[14] Krisafi Ksenofon Albanian Constitution and international law, published in 5 years constitution.

[15] Albanian Constitutional Court decision No. 186. Date, 23,09,2002.

[16] (Enzo Cannizzaro) The Law of Treaties Beyond the Vienna Convention the year 1986.

[17] The Law of Treaties Beyond the Vienna Convention the year 1969.

[18] "A Dictionary of Law". (2009).Universyty press. Oksford.

[19] "Charter of the United Nations" article 2,33,36,37.

[20] Gardiner, R.K. International Law. (Harlow: Longman, 2003) [ISBN 0582369762] page.98

[21] ICJ, North Sea Continental Shelf, ICJ Reports, 1969.

[22] The draft law on international agreements the Republic of Albania Article 78 and 83 paragraph 1 of the Constitution.

[23] Law number 182014 accession of the Republic of Albania in the Vienna Convention on the Law of Treaties between States and International Organizations and between International Organizations. 